\title{
Congress threat to technology transfer
}

[SAN DIEGO] The transfer of scientific technology from the three national laboratories of the US Department of Energy (DoE) to private companies is being threatened by a congressional proposal for resolving disputes over patent rights.

The proposal would require the three laboratories to offer an arbitration process that could result in substantial damage awards in patent disputes. At the moment, patent disputes are addressed in federal court or by the US Patent and Trademark Office.

Officials of the University of California which manages the Lawrence Livermore, Los Alamos and Sandia national laboratories for the DoE - say that the proposal could halt technology transfers because the financial risks to a public research laboratory would become too high.

University officials see no reason why the dispute procedures should change. They say that the proposal is a politically driven attempt by a small Alabama company to try to win the rights to a potentially valuable radar technology patented by a former Livermore scientist. The new technology, called micro-impulse radar (MIR), has wide application from sensor devices to wireless communication. The Alabama company, Time Domain Corporation of Huntsville, claims it has a right to MIR because it owns the patent from which this technology derives.

MIR technology is one of several discoveries licensed by Livermore to private firms as part of a nascent technology transfer programme worth more than $\$ 5$ million in annual licence fees.

But as the programme has grown, it has come under attack from at least two private companies which are developing products with technology similar to that licensed by Livermore. The companies complain that the government-funded laboratories are competing against them.

In one recent instance, a Californian company sought congressional assistance to win an agreement that would have blocked Livermore from developing a new type of battery with a zinc-air fuel cell. "It is inappropriate to do that," says Martin Simpson, a university attorney. "The new technology is a public asset that should be developed for the public benefit."

Ronald Cochran, Livermore's executive director, says that the energy department labs have never before experienced a dispute like the one currently involving Time

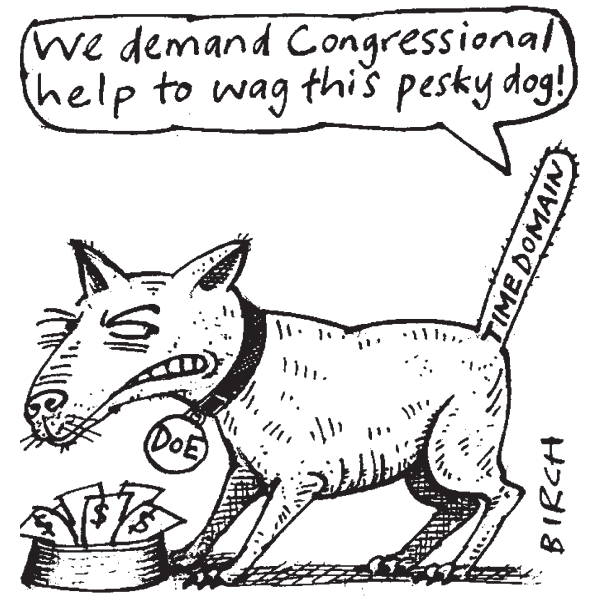

\section{Japan to launch ambitious genome project}

[токуо] Japan is to launch a national programme to identify and map single nucleotide polymorphisms (SNPs) in the Japanese population, according to a report released last week by the government's ad hoc working group on SNPs research.

The project will aim to map between 100,000 and 150,000 SNPs in two years, using samples obtained from at least 50 Japanese people. Data from other Asian populations will be added to the study at a later date.

SNPs represent the most abundant type of variation in the human genome, and can be used to map genes involved in common diseases such as diabetes and coronary heart disease.

Maps of this kind can also be used to identify individuals who are likely to be unresponsive to, or suffer side effects from, various drugs - allowing their doctors to choose the safest and most effective form of treatment for them.
The planned project will be carried out jointly by government ministries, universities and industry. It will create a public SNP database, which scientists hope will contribute to international efforts such as the SNP Consortium. This consists of 10 major pharmaceutical companies and five leading publicly funded genomics institutes, none Japanese (see Nature 398, 545; 1999).

Unlike programmes led by the SNP Consortium and companies such as Genset, which are based on genomic SNPs, the Japanese project will use SNPs in coding sequences by analysing full-length complementary DNA and expressed sequence tags.

But critics question Japan's ability to meet its projected target, given its relative weakness in information processing technology and sequencing capacity, and given the lack of Japanese firms that would be able to compete with Western biotechnology companies. Asako Saegusa
Domain, which has tried to use political pressure to muscle MIR technology from the federal laboratory.

Records and interviews show that Time Domain employs a former top DoE administrator to lobby the government. The company has funnelled more than $\$ 7,600$ into the coffers of Congressman Robert E. 'Bud' Cramer (Democrat, Alabama) and caused the US Patent and Trademark Office to reel under political pressure.

Ralph Petroff, Time Domain's president, says that his company, which has no products at the moment, is fighting for the MIR technology because it is derived from a US patent granted to the firm's scientific director, Larry Fullerton.

But electronics engineer Thomas E. McEwan, who holds more than 20 US patents associated with the MIR technology that he developed at Livermore before leaving the laboratory in 1996, says that Time Domain's contention is "absurd".

McEwan, who was named Distinguished Inventor of the Year in 1995 by the Intellectual Property Owners Association for his MIR work, said that his work differs fundamentally from that of Fullerton.

In an effort to resolve the dispute, Livermore asked the patent office to re-examine McEwan's MIR patent. But McEwan and university officials say the patent office has since come under political pressure from Time Domain advocates, something that the patent office denies.

At times, the battle has turned nasty. Time Domain and its advocates have hinted at a plot to deprive the company of its technology. McEwan says that Time Domain has repeatedly disseminated misrepresentations to smear him and win influence.

Time Domain could have sued in federal court to assert patent infringement, but chose not to because it would cost too much, says Petroff. But McEwan says the company is trying to use politics to win a battle it could not hope to win in court.

The proposal in Congress says the three laboratories must permit an aggrieved private company to seek arbitration, either binding or non-binding, in a patent or licensing dispute. If the company wins, it could, according to the proposal, demand damages and costs, which could fall on the DoE or the University of California.

Late last month, the House of Representatives passed a massive defence-spending bill that included an amendment for the national laboratory arbitration proposal. That measure will now be considered by a joint conference with the Senate in September. Another amendment with similar provisions for dispute resolution is to be voted on by the House early this month. RexDalton 